\title{
A Renegotiation Perspective on Transatlantic Trade Disputes
}

Heinz Hauser and Alexander Roitinger

A pril 2002 D iscussion paper no. 2002-09 
Editor:

Publisher:

Electronic Publication:
Prof. Jörg Baumberger

University of St. G allen

Department of Economics

Bodanstr. 1

CH-9000 St. Gallen

Phone ++41712242241

Fax ++41712242885

Email_joerg.baumberger@unisg.ch

Forschungsgemeinschaft für $\mathrm{N}$ ationalökonomie an der U niversität St. Gallen

Dufourstrasse 48

$\mathrm{CH}-9000$ St. Gallen

Phone $\quad++41712242300$

Fax $\quad++41712242646$

www.fgn.unisg.ch/public/public.htm 


\title{
A Renegotiation Perspective on Transatlantic Trade D isputes ${ }^{1}$
}

\author{
Heinz Hauser and Alexander Roitinger
}

Authors' address: $\quad$ Prof. Dr. Heinz Hauser

Alexander Roitinger, lic.oec.

SIAW -HSG

Dufourstrasse 48

$\mathrm{CH}-9000$ St. Gallen

Tel. $\quad++41712242578$

Fax $\quad++41712242298$

Email alexander.roitinger@ unisg.ch

W ebsite www.siaw.unisg.ch

1 Paper prepared for the Conference on Dispute Prevention and Dispute Settlement in the Transatlantic Partnership, Florence, 3-4 May 2002. W e are grateful to Thomas A. Zimmermann for helpful comments. 


\section{Abstract}

Transatlantic trade disputes seem to be a rising concern. According to the most critical voices, they provoke notable "trade wars" and crucially impair the credibility of the W TO dispute settlement mechanism. In this paper, we suggest that such conclusions are unwarranted. Violation of W TO agreements and non-compliance with Dispute Settlement Body rulings should be considered as an instrument for renegotiation with unique features, providing indispensable flexibility to the world trading system. Such flexibility is necessary because of incomplete contracting and "local" lack of commitment at the time of concluding agreements.

\section{Keywords}

D ispute settlement, W TO, non-compliance, trade wars, renegotiation, flexibility, incomplete contracting

\section{JEL Classification}

F02, F13, K33 


\section{Introduction}

A great number of theoretical and empirical studies have examined the performance of the WTO dispute settlement (DS) since its introduction in $1995^{2}$. Though there seems to be a widespread consensus that the mechanism is a useful tool for settling disputes, a significant number of problems have been identified. To begin with, it is doubtful that developing countries have equal opportunities to enforce their rights ${ }^{3}$. Secondly, some rulings have been criticised for their sole emphasis on promoting trade liberalisation, ignoring in particular environmental concerns ${ }^{4}$. Thirdly, the exact nature of settlement (i.e. the economic impact) is unknown in most cases and is possibly not in accordance with WTO agreements ${ }^{5}$. Yet, the most important problems - and we will focus on them - are apparently those related to disputed implementation of Dispute Settlement Body (DSB) rulings. Although the Dispute Settlement Understanding (DSU) sets a timeframe and urges the losing defendant to comply, there have been numerous delays, conflicts about interpretation of the text (especially as to the relationship between Art. 21.5 and Art. 22 DSU), severe threats, and high-profile cases of outright non-compliance.

Such implementation problems have been particularly relevant for the relationship between the United States (US) and the European Communities (EC). The disputes on bananas, beef hormones, and Foreign Sales Corporations (FSC) have received enormous publicity in this regard. And they are not expected to be the final ones. In fact, the situation seems to be so critical that two conclusions play a prominent role among observers. The first one characterises the US-EC-relationship and claims that we are undergoing a series of „trade wars“. This view is nurtured by aggressive speeches of politicians and the tendency to use the word „sanction“ when talking about the suspension of concessions or other obligations authorised by the DSB according to Art. $22 \mathrm{DSU}^{6}$. The second one is focusing on the specific role of the WTO in these conflicts and suggests that its credibility is severely at risk due to alleged ,failure" of the DS in resolving them.

In what follows, we will question these two conclusions. The violation of WTO agreements and the non-compliance with DSB rulings will be interpreted as flexibility instruments, which

\footnotetext{
See e.g. Bütler and Hauser (2000), Jackson (2001), Park and Umbricht (2001), or Hudec (1999).

See e.g. Hoekman and Mavroidis (2000) and section 4 below.

4 This attitude has been explicitly turned down by the Appellate Body in the Shrimp-Turtle case (WT/DS58). See Jackson (2001), p. $196 f$.

5 See section 3.
} 
enable countries to „locally“ renegotiate their commitments between multilateral rounds of liberalisation. Renegotiation might be motivated by political considerations only, but the provision of respective instruments can nonetheless be desirable from a purely economic point of view. Taking such a perspective, disputes are an inherent and implicitly required feature of the world trading order. They are about renegotiation, not about war. Even if a ruling does not lead to (rapid) compliance of the losing defendant, the credibility of the WTO DS is not impaired, as long as its function is properly understood.

The following section offers at first a „rule-oriented“ perspective on disputes and noncompliance. It should be understood as reference point for our own analysis. The conclusions of this perspective are confronted in section 3 with an alternative view, which highlights the importance of renegotiation as a consequence of incomplete contracting and „local“ lack of commitment. Violation of contract and non-compliance with DSB rulings represent an instrument of renegotiation that has some unique features, increases flexibility, and is therefore a useful element of the world trading order. It will be shown that members of the WTO have had in mind to endow the agreements with a good portion of such flexibility when concluding them. Section 4 formulates a cautionary note: Claiming that flexibility is an indispensable feature of the world trading order is neither suggesting that any kind of flexibility is desirable, nor that there is no need for provisions preventing abuse. With this qualification in mind, we continue in section 5 by assessing three important US-EC disputes in light of our renegotiation perspective. The last section concludes.

\section{A rule-oriented perspective}

When disputes arise after the conclusion of an international trade agreement, there are a number of different ways to deal with them. This holds even in the presence of an institutionalised DS mechanism. Analysts who complain about alleged failures of the WTO DS implicitly argue that the level of ,rule orientation“ among members is too low and that the best way to cope with such problems is to strengthen the bindingness of rulings.

For the purpose of our paper, we emphasise two distinct facets of rule orientation in an international trade agreement. The first facet is relevant whenever a member alleges that a breach of contract has occurred. Then, someone has to determine whether this allegation is true. Such adjudication does not only give a clue of what is „right” or ,wrong”. It also influences the

Charnovitz (2001) puts forward the thesis ,that although the instrument of suspending concessions or other obligations remains constant from GATT to WTO“, it was conceived primarily as „rebalancing“ under the 
distribution of contract value - as long as it is not completely disregarded by the affected parties. In this context, rule orientation would have to be contrasted with power orientation ${ }^{7}$. The latter predicts that adjudication results in a solution which reflects the difference in power of the countries. The more powerful country is expected to attain a more favourable outcome ceteris paribus. In contrast, a rule-oriented determination makes reference to norms and procedures previously agreed upon, is based on an equal footing of countries, and could include impartial third-party arbitration. It can be argued that such rule orientation has continuously gained support since the establishment of the GATT, notably due to a more and more legalistic DS process.

The second facet of rule orientation takes the determination of breach as given and deals with the nature of remedial action. In the WTO context, it is about implementation of a DSB ruling, and therefore about the legal effect of an adopted panel (or Appellate Body) report. Under a rule-oriented perspective, such a ruling creates an international legal obligation upon disputing parties to carry out the decisions of the $\mathrm{DSB}^{8}$. A losing defendant is consequently obliged to „specific performance“ as regards the adopted recommendations. Jackson examines the DSU and finds at least eleven clauses that support such rule orientation ${ }^{9}$. An opposite view would be that the losing defendant has free choice between compliance with the ruling, offering of concessions in other areas, or acceptance of retaliation in form of suspension of concessions or other obligations. The second facet of rule orientation is accordingly not contrasted with power orientation, but with flexibility of implementation.

It is this second facet that stands at the forefront of discussion today. There is indeed a debate about the question to which extent members of the WTO must be guided by rule orientation when implementing a DSB ruling ${ }^{10}$. This debate is of utmost importance, and from now on, we will implicitly have in mind this second facet whenever we talk about „rule orientation“. As indicated, supporters of strong rule orientation would argue that implementation problems of the WTO DS can be cured by strengthening the bindingness of DSB rulings. This might be achieved, for example, by either raising the authorised retaliation level in case of noncompliance, or by making WTO law directly applicable in all member states ${ }^{11}$. The latter sug-

former, and is primarily seen as a „sanction“ under the latter.

7 See Jackson (1997), p. 109ff.

8 See Jackson (1998), p. 169f., and Jackson (1994, 1997a).

9 See Jackson (1997a), footnote 11.

10 Schwartz and Sykes (2002), Sykes (2000), Bello (1996), or Ladreit de Lacharrière (1987) are prominent sources that reject the claim that there is a legal obligation to comply.

11 As to raising the level of retaliation, suggestions were made to introduce collective retaliation, see e.g. South Centre (1999). Pauwelyn (2000) suggests that compensation could be owed even during the period of applied 
gestion could mean that WTO agreements assume constitutional function on the national level.

There is no doubt that from a static perspective such rule orientation contributes decisively to the security and transparency of the world trading framework. However, applying a dynamic view which takes into consideration that agreements are concluded and maintained by forming expectations about their future usefulness, the rigidity incorporated in the bindingness of DSB rulings becomes an element of concern. As elaborated below, strict rule orientation is both not conducive to secure transatlantic relations, nor was it intended by the WTO contracting parties. Admittedly, rule orientation might eventually be the preferred way to settle a dispute, and indeed the DSU reads in Art. 3:7: „In the absence of a mutually agreed solution, the first objective of the dispute settlement mechanism is usually to secure the withdrawal of the measures concerned [...]“. Furthermore, Art. 22:1 DSU says that „,neither compensation nor the suspension of concessions or other obligations is preferred to full implementation of a recommendation to bring a measure into conformity with the covered agreements“. However, a preference per definitionem leaves room for alternative solutions. And it cannot be interpreted as an obligation to go ahead in a particular way. It remains to be shown that a DSB ruling has substantial significance even if it is not meant to create an irrevocable obligation to comply.

\section{An alternative perspective: Renegotiation and flexibility}

Flexibility, which can be understood as the provision of renegotiation opportunities between multilateral rounds of liberalisation, is essential for the success of an international trade agreement. Flexibility allows the parties to adapt to a changing environment. Such possibilities to adapt can be a precondition for dynamic maximisation of the gains from co-operation. Furthermore, it is necessary whenever countries should be induced to make far reaching longterm commitments.

In fact, rule orientation does not necessarily preclude renegotiation. After having demonstrated the need for renegotiation and its economic rationale, we will describe a number of „conventional“ instruments that can be used for such purpose. These are consistent with a rule orientation approach, since they are based on explicit provisions of the WTO agreements. However, these tools restrict flexibility to a sub-optimal level. The deficiency is removed if 
violation and non-compliance are allowed to be an implicitly accepted instrument for renegotiation. This instrument, if properly designed, enables the parties to choose an efficient level of flexibility without any prerequisites. It will be crucial to note that such flexibility must be costly and has a „local“ dimension only.

\section{Motivations for renegotiation}

There is an indefinite number of possible reasons why countries want to renegotiate an international trade agreement. We consider a very broad concept of renegotiation here and use the term whenever a country wants to undo or redefine a commitment ${ }^{12}$ between multilateral rounds of liberalisation. The country initiates an action, and subsequently provokes a response. Renegotiation is assumed to be about more protectionism, not about less ${ }^{13}$. Using this definition, it should be stressed that such behaviour must entail costs for the initiating country, since otherwise we would almost permanently be confronted with claims for renegotiation. Benefits and costs of actions to change the balance of commitments have to be understood in terms of political economy. International trade agreements are concluded between national governments, and these choose their individual trade policy by maximising a weighted sum of total political contributions from lobby groups and some aggregate social welfare (Grossman and Helpman 1994). The structure of optimal protection is vulnerable to changes in different variables, such as the degree of political organisation of lobby groups or the relative weight that the government attaches to political contributions compared to overall welfare ${ }^{14}$. The general economic climate, the election cycle or technological advance - to name just a few can also have substantial influence on the desired level of current protection. Such diversity of factors and the uncertainty characterising their development make it impossible to write an international agreement that anticipates the future and makes all actions (or prohibitions) contingent on the evolvement of these variables. From a government policy perspective, any agreement is therefore characterised by too much „rigidity“, i.e. the commitments are not made sufficiently dependent on the future state of the world. According to Battigalli and Maggi (2002), rigidity is one of two distinct forms of incomplete contracting, the other one being ,discretion“. Discretion is given when a contract does not specify the commitments with precision. Expectations about the behaviour of contract partners might be disappointed

enabling private parties to invoke international trade rules in claims brought before domestic courts.

12 Such as a tariff binding, the abolition of quantitative restrictions, or the protection of intellectual property rights.

13 This is of course a restrictive assumption, but it allows us to focus on the most critical issues.

14 See Grossman and Helpman (1994), p. 848. 
after the conclusion of an agreement. In short, both rigidity and discretion can make parties $e x$ post unhappy with their contract.

The conclusion therefore is that incomplete contracting represents a very broad and important category making the government wish to renegotiate. In the WTO context, incompletenessbased renegotiation often involves the interpretative contribution of the DS system, which serves to „clarify the existing provisions of those agreements in accordance with customary rules of interpretation of public international law“ (Art. 3:2 phrase 2 DSU). The role of the DS will be discussed in detail further below. Yet, it should already be noticed that panels or Appellate Body need not necessarily be able to fill the gap left by incomplete contracting. Art. 3:2 (phrase 3) DSU provides that: „Recommendations and rulings of the DSB cannot add to or diminish the rights and obligations provided in the covered agreements." This is not saying that the DSB is unable to contribute to a solution of the renegotiation process, by interpreting relevant rules in light of the overall agreement ${ }^{15}$. However, the wording of Art. 3:2 (phrase 3) DSU could indicate part of a losing defendant's justification for why he might be unwilling to comply with a ruling that redefines his commitments for a certain contingency.

Though incomplete contracting can in many instances explain why parties want to renegotiate, this is not its only source. The WTO agreements represent a contract which covers an immense field of trade (and related) topics and which includes at present 144 member countries. Negotiations in the run-up to the conclusion of the Uruguay Round were highly complex, and delegations finally came under considerable political pressure to achieve a successful result. It is very probable that some elements of the agreements remained contentious until the very last day of negotiation, and that they remained so even after signing. The successful conclusion of the Round was then an expression of the political will to reach an agreement on essential points. The contentious elements found their way into the agreement and might even have been given an unambiguous wording ${ }^{16}$. Yet, at the same time they were implicitly left for future renegotiation, last but not least by using violation and non-compliance as possible instruments. A „local“ lack of initial commitment, i.e. a missing consensus, therefore represents the second category causing the need for renegotiation. The term ,local“ is used to make clear that all parties support the overall contract and that the lack of consensus is limited to

\footnotetext{
15 Actually, concerns have already arisen in relation to the power of panels and Appellate Body, which, some say, are establishing new WTO law where existing rules are somewhat vague. See Laird (2001), p. 476, and Barfield (2001).

16 Abbott and Snidal (2000), p. 445, by contrast, describe the following solution in case that „one sticky problem threatens to upset a larger package deal“: ,Rather than hold up the overall agreement, states can incorpo-
} 
relatively few aspects. The Hormones case $^{17}$ seems to be a good example: The EC accepted the relevant rules of the SPS agreement, due to its integration into the broad framework of the Uruguay Round $^{18}$, but there has obviously never been an intention to overturn the inconsistent policy of banning hormone-treated beef.

\section{The global economic desirability of renegotiation}

The previous paragraph identified why individual parties to an international trade agreement may want to renegotiate. However, this establishes neither an individual economic desirability, nor the superiority of renegotiation from a global point of view, i.e. taking into account negative externalities on affected parties.

Global economic desirability would mean that an agreement incorporating well-defined instruments for renegotiation produces a higher level of social welfare in all member countries than an agreement excluding such a possibility. Yet, as a matter of fact, international trade agreements are not primarily concluded to maximise social welfare. A more realistic objective function has already been mentioned, based on a political perspective and consisting of a weighted sum of total political contributions from lobby groups and some social welfare. Consequently, renegotiation instruments would be favoured whenever they contribute to such governmental objectives.

If the aim were to make a positive analysis of renegotiation provisions in international agreements and to explain when and why they can be found ${ }^{19}$, one should follow such a political approach. On the other hand, any normative suggestion as to the desirability of renegotiation must take the global economic perspective. This is what we will attempt here. The argument can be summarised as follows: Renegotiation instruments find their way into international agreements such as the WTO because they are desirable from a global political point of view. However, they influence the government objective functions in such a decisive way that their omission could either prevent governments from initially concluding an agreement, or induce them to abandon an already signed contract. Since such an outcome would have strong negative economic effects, renegotiation opportunities can be desirable from a global economic perspective, too.

rate hortatory or imprecise provisions to deal with the difficult issues, allowing them to proceed with the rest of the bargain."

17 European Communities - Measures Affecting Meat and Meat Products (Hormones), complaint by the United States (WT/DS26).

18 See Davis (2001), p. 40.

19 This task would be in the spirit of Koremenos (2001). 
What makes renegotiation globally desirable from a political perspective? We will build on the insights from Rosendorff and Milner (2001), where two self-interested governments are confronted with political pressure from domestic lobby groups. This pressure is subject to shocks, but is only observable within national boundaries. Therefore, it cannot be included in a contract, and any international agreement on trade liberalisation remains incomplete. In such an environment, co-operation efforts are typically impaired by a prisoner's dilemma. A cooperative equilibrium in trigger strategies ${ }^{20}$ can only be sustained when the value $D$ of the present incentive for a government to defect is less than the discounted political value of future co-operation. For that to be the case, a small enough discount rate is required.

The agreement can now be enriched by a renegotiation device. Rosendorff and Milner allow each government to undo a commitment in any period by exercising an „escape clause“ and raising tariffs. Using this device comes at distinct costs in the amount of $k$, which enables the governments to withstand the temptation of permanently escaping. After a government has raised tariffs, it returns to the original tariff level in the next period - or exercises the escape clause again. Rosendorff and Milner go on to prove that there exists an agreement with escape possibility that represents a Nash equilibrium and pareto-dominates an agreement without such device. The escape clause as renegotiation instrument can therefore be desirable from a global political perspective.

Building on the results of Rosendorff and Milner, we will now characterise $k$, which can be generalised to represent the cost of any applied renegotiation instrument. It is crucial to note that $k$ must be chosen sensibly. A natural upper limit $U$ is the discounted value of future cooperation for the government. If $k$ exceeds that value, a government under pressure will abandon the contract, and not exercise the escape clause. On the other hand, if $k$ is set too low, we might just observe a somewhat modified prisoner's dilemma with both governments escaping permanently. For defining the lower bound $L$, it is important to be more explicit about the nature of these costs. As will be demonstrated below, the use of any renegotiation instrument by a country in the WTO context makes its government bear two cost components: a) A compensatory reverse movement in the balance of market access and b) a worsening reputation balance. Both components contribute to the objective function of the foreign government, which had been affected by the original withdrawal of the commitment. To be globally efficient from a political point of view, $L$ must be able to satisfy the „liability rule“21. It must be

\footnotetext{
20 A trigger strategy consists of the following instruction: Co-operate until a defection is observed, then punish forever!

21 See Schwartz and Sykes (2002).
} 
high enough so that the corresponding benefit for the foreign government compensates for the loss originally incurred.

It has been argued so far that the inclusion of a renegotiation instrument into an international trade agreement can lead to a superior global outcome from the perspective of self-interested governments. This requires that the cost $k$ of using the instrument is chosen from the efficiency interval $[L, U]$. To make sure that this interval is not empty, it is required of course that $L<U$. This is plausible whenever we have in mind a local renegotiation: The withdrawal of commitments is marginal in relation to the total amount of commitments included in the agreement, i.e. the overwhelming part of co-operation remains untouched.

We will now develop some considerations in order to indicate that renegotiation devices incorporated into an international trade agreement can be valuable even from a global economic point of view. In order to isolate the key reason for this claim, it is assumed that actual renegotiation decreases global social welfare as long as the respective action is maintained, due to its protective effects. If governments were not self-interested, an economic argument in favour of renegotiation devices would therefore necessarily fail. Consequently, we consider what happens in presence of self-interested governments. We first take an international trade agreement as given, and study two different cases:

Case 1: $D<U$

The present incentive $D$ for a government to defect is lower than the discounted political value of future co-operation $U$. In this case, the inclusion of renegotiation devices can only reduce global social welfare. The reason is simple: Co-operation is sustainable anyway, since no government wants to risk termination of the agreement. The inclusion of renegotiation devices would positively influence the objective functions of governments, but this comes at the price of lower social welfare in periods when they are actually applied.

\section{Case 2: $D>U$}

Under this condition, an international trade agreement would be abandoned if the possibility for renegotiation were excluded. For a self-interested government, the present incentive to defect is higher than the discounted value of future co-operation, and co-operation breaks down therefore. A renegotiation device would avoid this outcome as long as $k<U$. Assuming that the negative effect of actual renegotiation on global social welfare (as long as the respec- 
tive action is maintained) is outweighed by discounted future economic gains of co-operation, the renegotiation instrument is recommendable even from a global economic perspective.

There are two problems with our argument in Case 2. One is the concept of renegotiation proofness $^{22}$. It is difficult to believe that co-operation would break down forever absent a renegotiation device, even if a respective threat was explicitly pronounced. Such a threat would be time-inconsistent, given that future governments would have strong incentives to cooperate again, despite an earlier defection. Yet, an appropriate consideration of renegotiation proofness must depend on a highly specified model, which for simplicity is not envisaged here.

The second problem with Case 2 is the plausibility of the condition that the political gain of deviation today exceeds the political value of co-operation in all periods to come. We contend that politicians often have an extremely short time horizon. Due to the election cycle, future gains are discounted heavily or might not be valued at all. Short-term political gains from deviation, by contrast, can be the decisive factor for the survival of an incumbent government. Notwithstanding this argument, it is difficult to imagine a country abandoning e.g. the WTO. On the other hand, this difficulty might just be a consequence of the fact that the WTO has renegotiation devices.

So far, we have assumed that an international trade agreement exists. In addition, the argument for flexibility can be based on the claim that the agreement would not even be concluded in the first place without renegotiation devices - or that it would at least be much less comprehensive. Without flexibility provisions, governments might refrain from binding their hands if they expect that unforeseeable developments could make the withdrawal of commitments inevitable for political reasons. This reasoning seems plausible but has one important flaw. If we assume that a defection re-establishes the pre-contract situation, a rational government would commit itself until this unfavourable situation occurs. It could thereby temporarily reap the gains from co-operation, and return to the pre-contract world after defection. However, such behaviour would almost certainly entail substantial costs, for example due to an expensive initial negotiation process or due to the loss of reputation at the moment of defection. If these costs are higher than the expected gains from temporary co-operation, no agreement will be signed.

22 See e.g. Downs and Rocke (1995), p. 83f. 
It has already been mentioned that we use a broad concept of renegotiation, including all situations where a country wants to redefine or undo a commitment and therefore initiates an action, which in turn provokes a response. Looking at the WTO framework, such action could consist of „conventional“ means such as invoking a safeguard clause, arguing for a trade restriction based on a general or security exception, using explicit provisions for the launch of renegotiations on previous concessions, calling for a waiver or imposing anti-dumping and countervailing duties ${ }^{23}$. As explained further below, it makes perfect sense to add to this list the „unconventional“ act of simply violating the rules of an agreement and (possibly) refusing to comply with a subsequent DSB ruling.

Though the enumerated actions - which we call instruments for renegotiation - seem to be very different in nature, they have some important common properties. They all reflect the flexibility of the WTO agreements: If politically required by particular circumstances, members are enabled to withdraw certain commitments. The instruments allow the country to deviate locally without putting into question the overall adherence to the agreements (i.e. membership as such $)^{24}$. Instruments are interchangeable, though only imperfectly. Their relative attractiveness has changed over time - at different times, members opted for different instruments to engage in renegotiation ${ }^{25}$. Finally, each instrument is associated with distinct costs. However, the level of these costs is not uniform across instruments and further depends on the particular circumstances.

Is it really justified to talk about renegotiation when referring to measures such as invoking a safeguard clause, imposing anti-dumping duties, or even violating an agreement? Or are we just using a euphemistic expression for an inherently unilateral action that has not the least bargaining component? The answer is „yes“ to the first and therefore „no“ to the second question. Consider the obviously most drastic example: The violation of an agreement. In fact, the (potential) defendant does nothing but adjusting the level of concessions that he is

23 Anti-dumping and countervailing duties need not be seen as renegotiation devices when they are indeed directed against ,true“ dumping or subsidisation, however defined. In such cases, there is nothing to renegotiate, since there has never been an agreement on accepting such „unfair“ imports. Yet, looking at the practice of anti-dumping and countervailing duties and the attitude of panels and Appellate Body in relevant cases, it seems that countries have substantial leeway in interpreting dumping or subsidisation. They are obviously allowed to take measures beyond of what is considered to be a re-establishment of ",fair trade“.

24 Koremenos, Lipson and Snidal (2001) call this an „adaptive institutional flexibility“: „The general goal is to isolate a special problem - such as a spike in steel imports from a few producing countries - and insulate the broader institution (in this case, the GATT/WTO) from its impact" (p. 773).

25 See Finger (1998). The anti-dumping instrument has strongly gained attractiveness since the mid-eighties. Recently, more and more developing countries discovered its apparent usefulness. 
ready to give in exchange for the current level of concessions provided by his trading partners. The latter can then decide if they are ready to accept the new balance of concessions (and therefore refrain from acting themselves ${ }^{26}$ ), or if they consider that the violation needs to be countered with an adjustment of their own. Taking a dynamic perspective, this mechanism of adjustment reflects a bargaining situation as long as members are ready to participate. For this to be a realistic picture of the world trading order, there must be some deterrent elements which provide a certain amount of stability. This deterrence is represented by the cost of such an instrument.

When using one of the renegotiation instruments, the initialising country intends to achieve an improved balance of mutual market access in a particular sector. This balance describes the country's sectoral access conditions on the respective foreign market in relationship to the foreign access on the home market ${ }^{27}$. As regards the downside of such improvement (i.e. the downside of the applied instrument), there is generally ${ }^{28}$ a trade-off between two kinds of cost: A compensatory reverse movement in the balance of market access (possibly in various sectors) on the one hand, and a worsening reputation balance ${ }^{29}$ on the other hand. There is little reputation loss if the withdrawal of a commitment is accompanied by (market access) concessions in other sectors, or by a bilaterally negotiated reciprocal withdrawal of commitments by the affected trading partner(s). In contrast, if a member uses renegotiation instruments that are not directly connected with a compensatory change of market access (e.g. an anti-dumping action or a violation of agreement), it suffers higher reputation costs. Adding up compensatory market access costs and reputation loss, the total cost of each instrument is determined. Since it is difficult to properly calculate market access costs and virtually impossible to quantify reputation loss, theory cannot provide an exact ranking of instruments according to their attractiveness. Yet, one can investigate empirically which instruments seem to be favoured by the political process at different points in time ${ }^{30}$.

26 It is a well-known fact that not all violations of WTO agreements are litigated, see Sevilla (1997).

27 See Hillman and Moser (1996) for a political economy analysis of market access exchange in the transatlantic context.

28 Both a) the general or security exception (Art. XX and XXI GATT) and b) the waiver (Art. XXV.5 GATT) have no attributable costs. Yet, due to the narrow applicability of (a) and the two-thirds majority requirement of (b), they are of very limited use for renegotiation purposes.

29 This balance is an expression for the relative reputation levels accredited to countries. It influences the relative positions of countries in future negotiations. Kovenock and Thursby (1992) acknowledge such costs and ascribe them to the breach of ,international obligation“. They argue that: ,[...] we can think of this disutility as a loss of goodwill in the international arena or the political embarrassment that comes from being suspected of violation [...].“ (p. 160). Bown (2001), however, does not find empirical evidence that supports the significance of this cost factor.

30 Such analysis was performed e.g. by Finger (1998). However, he does not include the violation instrument. 
The instruments discussed do not only show a different cost structure (and a different level of total cost), they can also be distinguished by the prerequisites that have to be fulfilled before they can be used. The prerequisites describe the applicability of an instrument. It is easy to see that the violation of an agreement has the broadest applicability: There are by definition no prerequisites to fulfil. Once again, a trade-off can be observed: Instruments with a high level of prerequisites tend to have a low reputation effect. Actions that can be taken without any precondition generally induce more reputation loss.

The following table provides a selective comparison of different instruments for renegotiation:

\begin{tabular}{|c|c|c|}
\hline Instrument & Prerequisites & Costs \\
\hline $\begin{array}{l}\text { Safeguard Clause } \\
\text { [Art. XIX GATT] }\end{array}$ & $\begin{array}{l}\text { Imports in such increased quantities } \\
\text { as to cause or threaten to cause } \\
\text { serious injury to domestic produc- } \\
\text { ers; due to unforeseen developments } \\
\text { and GATT obligations; Notification }\end{array}$ & $\begin{array}{l}\text { Affected parties can ask for com- } \\
\text { pensation. In case no agreement is } \\
\text { reached, they are then free to sus- } \\
\text { pend substantially equivalent con- } \\
\text { cessions }\end{array}$ \\
\hline $\begin{array}{l}\text { General (or Security) Exception } \\
\text { [Art. XX and XXI GATT] }\end{array}$ & $\begin{array}{l}\text { No arbitrary or unjustifiable dis- } \\
\text { crimination; No disguised restric- } \\
\text { tion on international trade; Only } \\
\text { applicable for a narrow number of } \\
\text { purposes }\end{array}$ & None \\
\hline $\begin{array}{l}\text { Explicit Renegotiation Provisions } \\
\text { [Art. XXVIII GATT] }\end{array}$ & $\begin{array}{l}\text { Only at the end of a three-year pe- } \\
\text { riod or, if authorised, in special } \\
\text { circumstances; General level of } \\
\text { reciprocal concessions should re- } \\
\text { main unchanged }\end{array}$ & $\begin{array}{l}\text { Affected parties can ask for com- } \\
\text { pensation. In case no agreement is } \\
\text { reached, they are then free to sus- } \\
\text { pend substantially equivalent con- } \\
\text { cessions }\end{array}$ \\
\hline $\begin{array}{l}\text { Waiver } \\
\text { [Art. XXV.5 GATT] }\end{array}$ & $\begin{array}{l}\text { In exceptional circumstances not } \\
\text { elsewhere provided for in the } \\
\text { GATT; Approval by a two-thirds } \\
\text { majority of votes cast }\end{array}$ & None \\
\hline $\begin{array}{l}\text { Anti-Dumping or Countervailing } \\
\text { Duties [Art. VI GATT] }\end{array}$ & $\begin{array}{l}\text { Dumped or subsidised imports that } \\
\text { cause or threaten to cause material } \\
\text { injury to a domestic industry; Duties } \\
\text { may not exceed dumping or subsidy } \\
\text { margin }\end{array}$ & $\begin{array}{l}\text { Reputation loss if applied exten- } \\
\text { sively; Retaliation }\end{array}$ \\
\hline Violation of Agreement & None & $\begin{array}{l}\text { Reputation loss; Potential sanctions } \\
\text { if DSB ruling is disregarded }\end{array}$ \\
\hline
\end{tabular}

$\underline{\text { Table 1: Prerequisites and costs of renegotiation instruments }}$

$\overline{31}$ See Blonigen and Bown (2001). 
It has been demonstrated so far that provisions for renegotiation can be considered as valuable attributes of international agreements, even from a global economic perspective. Furthermore, there is a variety of instruments that can be used for such purposes. It has been argued that violation and non-compliance, too, share characteristics of renegotiation devices. What remains to be done is answering two related questions: a) If there are so many conventional renegotiation instruments at disposal, why do we still need an unconventional one? b) Be it valuable or not, did the contract parties of the WTO actually opt for such an instrument when signing the agreements?

All renegotiation instruments have a common purpose: Providing the international trade agreement with flexibility as regards the observance of commitments. At the time of signing an agreement, the parties know that a) the future is full of uncertainty and b) some of their commitments are only made to secure the conclusion of the overall contract. Taking this into account, the stipulation that the use of renegotiation instruments is conditional on the fulfilment of predefined prerequisites neglects the motives for renegotiation. Future states of the world might force self-interested governments to take measures even if the revealed state does not correspond to one of those contractually described as prerequisite. And a local lack of commitment means that the government has never intended to comply with the respective rule, independently of a particular state of the world. In that sense, all conventional renegotiation instruments create flexibility - but their prerequisites cannot take account of all contingencies which would warrant a renegotiation of commitments.

The violation of an agreement and non-compliance with a DSB ruling are not based on the fulfilment of any prerequisites. Consequently, they have an unlimited applicability and can provide flexibility in all those states of the world where conventional renegotiation instruments are not available.

Bown (2002) suggests that countries withdrawing a commitment always choose the instrument that puts themselves into the most favourable bargaining position. Translating this into our language, the violation of contract will be chosen if (and only if) it has a more attractive cost-benefit structure than the conventional alternatives. Concretely, Bown provides a theory as regards the decision of a country to afford ,illegal“" protection (leading to a dispute) instead of using ,legal“ safeguards. The choice seems to depend primarily on the characteristics of the affected trading partner. The key insight is that the (expected) compensatory reverse 
movement in the balance of market access is not the same when using legal and illegal protection $^{32}$. Particularly, illegal protection is more likely applied if the affected trading partner has limited capabilities for retaliation. Though Bown's analysis is appealing, it misses the fact that the two forms of protection not only differ in their cost level, but that they are rarely substitutes. Referring to the tabulated differences with regard to prerequisites, safeguards are inherently designed to protect domestic producer interests in times of rising imports. Yet, political pressure for renegotiation might increasingly come as well from other groups, such as consumers or environmentalists. The Hormones case is again a good example. Furthermore, political pressure from producers is not only correlated with import levels and their growth rate, as the current transatlantic steel conflict confirms ${ }^{33}$. In summary, there is good reason to believe that members occasionally search for a renegotiation instrument even if a legal safeguard measure is not at disposal.

Not all violations finally lead to non-compliance. If incomplete contracting represents the origin of a dispute, a losing defendant might accept the contract interpretation by panel or Appellate Body and withdraw his renegotiation device. This is not unrealistic, since the DSB ruling increases the cost of the applied instrument and can make its use disadvantageous. This cost argument is also true if a local lack of commitment causes the violation of a WTO agreement. Furthermore, such lack - and the underlying protectionist pressure - might have been temporary anyway and disappear until a DSB ruling is rendered. If, however, the motive for renegotiation is strong enough and its benefit exceeds the cost imposed by the DSB, noncompliance will occur. The implementation of a DSB ruling will then be delayed until an undetermined point of time in the future.

In essence, the previous paragraph is merely a positive analysis of rational behaviour of selfinterested actors. As further detailed in the next subsection, these actors opted for a significant degree of flexibility when establishing the WTO. The rules of the agreements are designed to allow a breach of contract, but at the same time to limit its extent and to compensate those who are negatively affected. The WTO DS mechanism fits perfectly into this concept, and the

32 This holds even after the introduction of the new DSU and the Safeguards Agreement.

33 According to the European Commission, US steel imports have fallen by 33 percent since 1998, see Neue Zürcher Zeitung, 7 March 2002, p. 23. Nonetheless, political pressure became so high that the Bush administration decided to take safeguard measures in March 2002. 
critique of lacking credibility is probably caused by the fact that its primary function is not properly understood ${ }^{34}$. The DSU states in Art. 3:2 that:

„(1) The dispute settlement system of the WTO is a central element in providing security and predictability to the multilateral trading system. (2) The Members recognise that it serves to preserve the rights and obligations of Members under the covered agreements, and (3) to clarify the existing provisions of those agreements in accordance with customary rules of interpretation of public international law." 35

Based on the considerations presented above, we argue that the WTO DS cannot do justice to (1) if flexibility is restricted disproportionately. The task in (2) can be understood as assigning costs to the use of flexibility. It is suggested therefore that the function of the WTO DS should be described so far as being twofold: a) Confirming violation of an agreement, thereby affecting the reputation balance between complainant and defendant. b) Defining the level of lawful retaliation and making it public ${ }^{36}$. By exercising these functions, the DS process establishes the two cost components of potential non-compliance and sets the frame for a new bargaining situation between complainant and defendant.

The description of the first function seems to ignore the role of adjudication and clarification as requested in (3) by emphasising confirmation of violation only. However, as a matter of fact, the DSB almost always supports the complainant ${ }^{37}$, making confirmation of violation the typical result of panel and Appellate Body activity. Explanations for this pro-complainant attitude are primarily based on the differing incentive structure of complainant and defendant as regards the settlement before a DSB ruling ${ }^{38}$.

It should be emphasised that the numerous innovations of the new DSU have reinforced the purported functions of the WTO DS. The greatest achievement is that their exercise will not be undermined anymore by the defendant blocking a ruling. Although the latter is still capable of violating an agreement and rejecting the removal of an initial trade measure after a ruling, there is no possibility to avoid the confirmation of violation and the determination of compulsory costs. On the other hand, it is now explicitly excluded that the two functions are undertaken by some self-designated national authority. As Art. 23:2 DSU formulates, „Members

\footnotetext{
34 There is considerable disagreement about the main function of the DS process. Bello (1996) suggests that ,the fundamental nature of WTO dispute settlement is either misunderstood or mischaracterised by its detractors“ (p. 418).

35 Numbers added.

36 This transparency is of utmost importance since it guarantees that protectionism is not regarded as a free lunch by the public.

37 Reinhardt (2001), p. 180, notes: „,T] he parties already know what their obligations are: the [DSB] ruling is just a formality whose likely content the disputants could often agree on in advance." He observes a proplaintiff bias in those cases decided by a panel on the order of 4 to 1 for the GATT period.
} 
shall not make a determination to the effect that a violation has occurred, that benefits have been nullified or impaired [...], except through recourse to [the WTO] dispute settlement".. In fact, it is not the determination that is dangerous, but its consequences. As the requests for authorisation of suspension of concessions generally show, members negatively affected by non-compliance tend to exaggerate the incurred nullification or impairment ${ }^{39}$. If we understand the violation of an agreement as a renegotiation instrument, such a distortion in the representation of costs would impair its usefulness. Hence, it is of utmost importance that there is an objective measurement of damage, exercised by an independent body.

This reform is strengthened by some additional features characterising the new DSU. First of all, there is now an almost unified process for disputes under all WTO agreements ${ }^{40}$. This is efficiency enhancing in many respects, but it particularly underlines that the activity of the DS should not depend on the nature of violation. In fact, it would be an artificial restriction of flexibility without theoretical foundation if the possibility to renegotiate were made contingent on characteristics of goods or industry type. And indeed, it would crucially reduce the persuasiveness of our argument that the WTO DS has exactly the functions described above.

Secondly, the complainant now has substantial agenda-setting power ${ }^{41}$. Together with an extremely tight time frame (Art. 12 and 17 DSU) for the work of both panels and Appellate Body $^{42}$, this ensures that the tasks of confirmation of violation and the determination of costs are not unduly delayed. Although an expeditious procedure cannot substitute for retroactive imposition of costs on violators, it contributes to limiting the time of free riding.

Thirdly, the possibility of an appellate review and the characteristics of the standing Appellate Body make sure that the confirmation of violation is based on an accurate and perfectly reliable assessment of facts. This does not only increase the predictability and credibility of rulings, but is especially important for a successful impact on the reputation balance as requested by the first function of the DS process. If rulings were based on an arbitrary determination, the reputation of the (losing) defendant would scarcely be affected.

\footnotetext{
38 See e.g. Bütler and Hauser (2000).

39 In the Bananas case, for example, the US calculated the level of nullification or impairment to be 520 million USD, compared with 191 million USD authorised by the DSB. In the Hormones case, the numbers were 202 and 117 million USD, respectively.

40 The unification is subject to some special rules and procedures identified in Appendix 2 of the DSU. Jackson (1997) notes in this respect: „The central core process, however, is unified“ (p. 125).

41 See Bütler and Hauser (2000), p. 509.

42 Compared to other instances of international litigation, such as the International Court of Justice or the International Tribunal for the Law of the Sea, see Rosas (2001), p. 138.
} 
Indeed, the blocking of a ruling was not always without cost in the past, since it conceivably might have had a negative reputation effect and could have provoked retaliation, though unauthorised. Yet, although blocking was a strong indication of violation, it was no confirmation. And initialising unauthorised retaliation meant that this cost component was set at an arbitrary level. In essence then, the new DSU has strengthened the cost concept as the counterpart of flexibility. This has not been done by dramatically raising the average cost of noncompliance, but my making the cost components steadier, more reliable, and predictable.

In this light, one could explain the observation that alleged problems with implementation in general and cases of non-compliance in particular have increased in recent years ${ }^{43}$. This is particularly true for disputes between the US and the EC. There are three principal reasons for this development. First of all, the broader coverage of the WTO agreements and the larger membership induce more disputes and thereby more cases in which non-compliance is an issue. Secondly, the surprisingly low number of non-compliance cases in the past is partly explained by the described possibility of a defendant to block a negative outcome at various stages of the old DS process. It could be argued that such blocking was a form of early noncompliance with an expected unfavourable ruling. Thirdly, and most importantly, the often cited increasing confidence in the working of the new DS mechanism can also be interpreted as a growing recognition of its renegotiation aspects. Governments realise that the comprehensive agreements of the Uruguay Round have substantially restricted their trade policy independence, yet that there is a DS process which allows them to „buy“ some flexibility and „pay“ a properly determined price for it.

\section{Two casual observations regarding the WTO DS process}

The rule-oriented perspective has been confronted with theoretical reasoning that underlines the importance of violation and non-compliance in an international trade agreement. Furthermore, the previous paragraphs have shown that the explicit objectives of the DSU are consistent with our renegotiation perspective. Yet, consistency alone does not prove that members of the WTO have actually had in mind to endow the agreements with a good portion of such flexibility when designing them. For that purpose, a more detailed examination of formal DSU provisions would have to be performed. This has already been done at least partly else-

\footnotetext{
43 See Pauwelyn (2000), p. 335f., or Jackson (2001), p. 191. Under the GATT, a suspension of concessions has been authorised only once (Netherlands - Measures of Suspension of Obligations to the United States, 1953). Under the WTO, there have been seven cases displaying outright non-compliance, see Footer (2001), p. 95. It is expected that there will be an increasing number of cases in the future in which non-compliance is an issue, see Jackson (2001), p. 193, Valles and McGivern (2000), p. 63, or Gleason and Walther (2000).
} 
where ${ }^{44}$, and we therefore highlight just two casual observations about the WTO DS process that are particularly supportive for our claim: a) Bilateral negotiations to find a mutually acceptable solution are de jure and de facto the preferred tool for the settlement of disputes. b) When bilateral negotiations fail to prevent the DSB from issuing a ruling, and the defendant refuses to comply, there is de facto no enforcement effort. These observations are clear evidence that members intended to allow flexible implementation of rulings.

As to the first observation, the DSU asks that bilateral negotiations take place before and during the formal DS process. This is obviously a desired feature, and Jackson concludes: „One encouraging characteristic of the cases brought so far is that a large number are settled, in the sense of never leading to a panel report ${ }^{\star 45}$. We definitely agree, but suggest that the desirability of bilateral negotiations does not end at the moment of a DSB ruling. If a mutually acceptable solution ,is clearly to be preferred“ (Art. 3.7 DSU), there is no logical argument that invalidates this statement for the time after a DSB ruling. In fact, only the negotiation after a ruling can profit from a more equilibrated balance of bargaining positions due to the assignment of costs to the (losing) defendant by the DSB.

There is another crucial point that should be emphasised. The DSU requires that any solution found in bilateral negotiations shall be consistent with the WTO agreements (Art. 3.5 DSU) and be notified to the DSB (Art. 3.6 DSU). It is evident that the first request is almost useless without the second, but that notification is rarely taken as seriously as one might hope. However, even in cases where bilateral solutions are properly notified and in principle consistent with the agreements, caution is advisable in judging their economic success. There is a strong presumption that defendants are tempted to keep the substance of an initial violation, but to find an arrangement which circumvents WTO rules and is difficult to challenge therefore ${ }^{46}$. Although one might think that this is equally true for bilateral settlements before and after a DSB ruling, it is plausible to assume that the transparency of a solution is significantly higher in the second case. A DSB ruling does not only alter the bargaining positions, it also directs international attention to the dispute. The more ,problems“ arise with the implementation of a ruling, the more certain it is that the media are carefully tracking any attempts of rapprochement between the parties and reporting the results. In addition, the DSB itself keeps under surveillance the implementation process, not at last in case of non-compliance (Art. 22:8

\footnotetext{
44 See particularly Schwartz and Sykes (2002) and Sykes (2000) in reply to Jackson (1997a).

45 See Jackson (2001), p. 190.

46 See e.g. Zimmermann (2001), who makes that argument in respect of the case Canada - Certain Measures Concerning Periodicals, complaint by the US (WT/DS31).
} 
DSU ${ }^{47}$. An eventual settlement that comes after a ruling might therefore be much closer to the rules than a more or less unnoticed deal in the run-up to a DSB ruling.

The second observation is the de facto absence of enforcement in the WTO DS process. It is important to distinguish two aspects of this absence. One is that there has always been a natural limitation of all enforcement efforts. Sovereign countries cannot be forced to behave in a particular way as long as drastic measures (such as embargoes or military intervention) remain excluded. However, this does not mean that all enforcement efforts are useless, and this brings us to the second aspect. Countries can consciously create artificial limits of enforcement that are (far) below the natural limits.

What leads us to the conclusion that the natural potential for enforcement is not exploited in the WTO? A first indication is that panels and Appellate Body generally refrain from suggesting specific implementation measures. Although they are allowed to formulate such suggestions $^{48}$ - and are indeed called upon to do so $^{49}$-, they rarely go beyond ,standard recommendations“. Three points follow immediately: Defendants are not convincingly discouraged to permanently maintain at least part of the protective element of their initial violation ${ }^{50}$. Secondly, due to the lack of guidance, any implementation is delayed. Last but not least, the final determination whether compliance has occurred needs greater scrutiny.

Enforcement is further weakened by the strictly limited market access costs that the DSB imposes in case of non-compliance. The only function of such costs seems to be restoring the balance of concessions, which can be deduced - as regards retaliation - most obviously from Art. 22:4 DSU: „The level of the suspension of concessions or other obligations authorised by the DSB shall be equivalent to the level of the nullification or impairment." Due to the difficulties in calculating reputation costs, it cannot formally be proven here that total costs $k$ for non-compliance (i.e. market access costs plus reputation costs) are actually lying in the efficiency interval $[L, U]$ as requested by the theory of flexibility. However, it is contended that the signatories of the WTO at least had this interval in mind when designing the enforcement rules. The aim of restoring the balance of concessions is clearly inspired by $L$ : Even if reputation costs are low or almost absent, $k$ should not fall short of the lower limit of the interval.

47 Admittedly, it is not quite clear how effective this surveillance is.

48 Art. 19:1 DSU provides that: „In addition to its recommendations, the panel or Appellate Body may suggest ways in which the Member concerned could implement the recommendations."

49 See e.g. Hoekman and Mavroidis (2000), p. 530, or Pauwelyn (2000), p. 339.

50 Horn and Mavroidis (1999) argue that: „When limiting themselves to recommendations, WTO adjudicating bodies give ample discretion to the losing party. WTO Members are then, in principle, free to adopt any conduct they deem necessary in order to bring their measures in conformity with their international obligations." 
On the other hand, $k$ by far misses the maximum thinkable cost level of non-compliance. Retaliation is strictly limited in its scope and duration ${ }^{51}$. Only the complainant is allowed to retaliate, and there are restrictions as regards the choice of products for retaliation (Art. 22.3 DSU). Cross retaliation encounters problems ${ }^{52}$, and so-called carousel retaliation is heavily disputed $^{53}$. In fact, market access costs are not only below the maximum thinkable level, they are also below $U$. This can be seen if the discounted value of future co-operation for the government is approximated by today's political value of membership. Since non-compliance is not ,punished“ with the denial of membership, the signatories wanted to keep $k$ below $U$.

\section{A cautionary note}

In the last section, we discussed the value of flexibility and the features of violation and noncompliance that make them a useful instrument for renegotiation. Such flexibility was indeed intended by the signatories of the WTO. Before assessing some important US-EC disputes in light of these findings, we should make a cautionary note to avoid possible misinterpretations of our proposition. Claiming that flexibility is a useful feature of the world trading order is neither suggesting that any kind of flexibility is desirable, nor that there is no need for provisions that prevent abuse. The critical task of determining the cost for each renegotiation instrument within the efficiency interval $[L, U]$ has already been emphasised. It seems, for example, that the substantial leeway granted in interpreting dumping or subsidisation provides countries with an instrument of renegotiation that is extremely cheap, possibly too cheap, whenever reputation does not play a major role ${ }^{54}$. It does not come as a surprise therefore that an abundant use was made of it in the recent past. Furthermore, the virtual refusal to impose retroactive market access costs in most disputes ${ }^{55}$ reduces - for a considerable time - the total cost of flexibility to mere reputation loss.

51 For guidelines as regards the calculation of nullification and impairment see WT/DS26/ARB, para 36ff, and WT/DS27/ARB, para 6.3ff. Difficulties with this concept are discussed in Breuss (2001), p. 32ff. As to the duration of retaliatory measures, they have to be terminated as soon as compliance is achieved.

52 See Vranes (2001).

53 See WT/DS200 and Sek (2001).

54 It was decided at the Ministerial Conference in Doha that there will be negotiations about „clarification“ of anti-dumping and countervailing duty rules, see WTO Document No. WT/MIN(01)/17. Recently, in the dispute European Communities - Anti-Dumping Duties on Imports of Cotton-Type Bed Linen From India, complaint by India (WT/DS141/AB/R), the Appellate Body held that the practice of ,zeroing“"when establishing ,the existence of margins of dumping“, as applied by the European Communities, is inconsistent with the Anti-Dumping Agreement. The Appellate Body thereby raised the cost of using this instrument.

55 Some of the rare retroactive effects were evident e.g. in WT/DS126, where the panel concluded that ,the SCM Agreement is not limited to purely prospective action but may encompass repayment of prohibited subsidies“, see Rosas (2001), p. 141. 
Another concern has to be raised when flexibility is not distributed evenly among countries. We abstracted from this problem so far, since the transatlantic relationship is rather one of equal than unequal partners. Taking a broader perspective, however, it must be recognised that differences in power crucially affect the availability of flexibility for individual countries. Small countries risk to be denied any renegotiation instrument by the implicit threat of powerful nations to impose additional costs on them inside and outside the WTO sphere. As an example, both the US and the EC might credibly threat to stop development assistance (e.g. in form of the Generalised System of Preferences) if a developing country does not comply with a DSB ruling. On the other hand, powerful countries might get flexibility too cheaply when applied against small nations because the latter could be unable to retaliate due to their foreign trade structure ${ }^{56}$. Bown (2002) shows how (powerful) countries in need of trade policy flexibility take advantage of the affected nations' characteristics when choosing their renegotiation instrument. It is very plausible to assume that they sometimes manage to push down costs far below $L$.

That said, we do not think that such arguments can undermine the claim that flexibility is valuable and that a strict rule orientation is not desirable. In particular, one does not get rid of power imbalances by just strengthening rules. Instead of condemning flexibility, mechanisms should be designed that guarantee an equal distribution of flexibility and an appropriate cost level. Although this is not easy and certainly out of reach for this paper, it merits at least as much attention as the debate about means for strengthening rule orientation.

\section{A new assessment of important disputes: Bananas, Hormones and FSC}

After this cautionary note, we attempt to assess three important US-EC disputes in light of the findings about flexibility. Much has been written about the cases Bananas, Hormones and $F S C^{57}$. They will not be portrayed in detail now. Instead, we focus on describing those elements that allegedly caused some kind of failure of the WTO DS and that obviously disrespect a rule-oriented behaviour. Afterwards, it will be attempted to step back from such negative judgement and to look at the three cases from a renegotiation perspective.

\footnotetext{
56 As a consequence, we would expect that small countries bring fewer complaints against powerful ones. However, Horn, Mavroidis and Nordström (1999) do not find evidence in this respect.

57 An excellent „road-map“ to the Bananas dispute is provided by Salas and Jackson (2000) and Jackson and Grane (2001). The Hormones dispute is thoroughly analysed in Davis (2001). As to the FSC case, see e.g. Skeen (2000).
} 


\section{A short review}

In 1993, the EC introduced a regulation establishing a harmonised regime on the importation of bananas. It consisted of a tariff quota system and continued historical privileges for ACP countries. These privileges had already been challenged before by a group of Latin American countries, but the EC and the ACP countries had blocked the panel report ${ }^{58}$. The same happened with a second panel report ${ }^{59}$ in 1994. After the conclusion of a bilateral settlement with the original complainants and after the signing of the Uruguay Round agreements, a new group of countries (including the US and Ecuador) filed a complaint. For the third time, the EC lost the case in front of panel and Appellate Body ${ }^{60}$, whose reports were adopted on 25 September 1997. The EC seemed to accept the ruling by requesting consultations as to the „reasonable period of time“ for implementation (Art. 21 DSU). An arbitrator decided that compliance with the ruling had to be reached by 1 January 1999. The EC made some amendments to the banana regime, yet these did not satisfy the complainants. A controversy started about the relationship between Art. 21.5 and 22 DSU, i.e. about the question when the right to retaliate arises. Not surprisingly, the EC pushed for a renewed (and lengthy) DS procedure, which should have to determine if the amended regime was consistent with the DSB ruling. The US on the other hand openly threatened to retaliate and indeed requested authorisation to suspend concessions only two weeks after the end of the officially granted implementation period. This request was withdrawn in order to enable arbitration on the appropriate level of retaliation (Art. 22.6 DSU). After the arbitrators had requested further information on 2 March 1999 and thereby postponed a decision, the US nonetheless started to suspend customs clearance for a number of products on the next day. This step was subsequently challenged by the $\mathrm{EC}^{61}$. About one month later, the arbitrators finally determined the appropriate level of retaliation, which was set significantly lower than requested by the US. The EC did not appeal, and the US imposed retaliatory tariffs with an impact of 191 million USD. In May 2000, the US further increased pressure by adopting a so-called carousel provision ${ }^{62}$, which brings about a periodical change of products affected by retaliatory tariffs. A large number of EC exporters were therefore confronted with significant uncertainty as to the actual access conditions on US markets. The EC requested consultations ${ }^{63}$, but no additional steps in the DS pro-

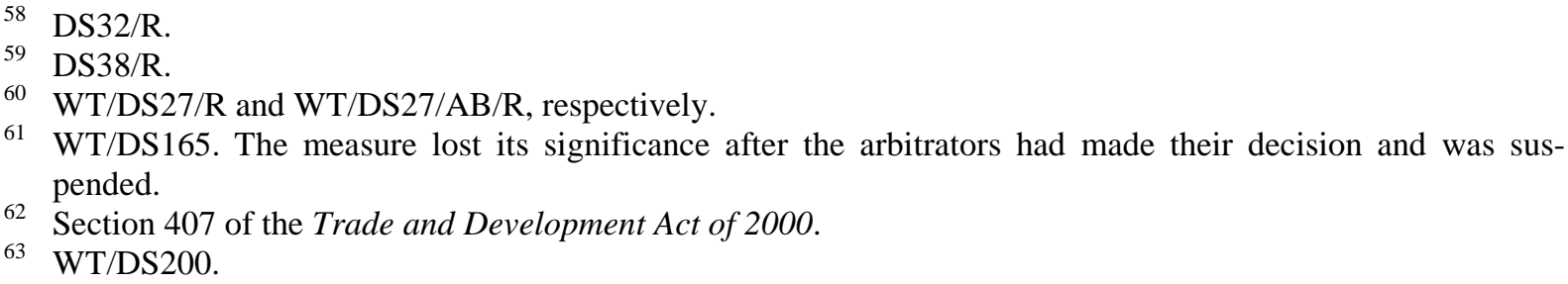


cess were taken. On 11 April 2001, a bilateral agreement was reached between the US and the $\mathrm{EC}^{64}$. The latter accepted to crucially modify the banana regime, leading to a tariff only system, due to start on 1 January 2006 at the latest. The US suspended in return its sanctions on 1 July 2001, and they were permanently lifted after the EC adoption of the amendments ${ }^{65}$.

There has been a long conflict across the Atlantic about the use of growth-promoting hormones. During the 1980s, the EC gradually reinforced their negative stance towards such additives. This development occurred despite a substantial number of scientific work that found no indication of risk for human health. In 1989, the EC banned imports of red meat from animals treated with six key growth hormones. The US, traditionally an important exporter of hormone-treated beef, claimed that these measures represented a barrier to trade inconsistent with GATT rules. Similar to the Bananas case, all attempts to have this practice officially condemned by GATT authorities failed due to the blocking by the EC. The US countered with unilateral sanctions. Under the WTO, consultations about the disputed import regime started in 1996, a panel report was distributed on 18 August 1997, and the Appellate Body released its ruling on 16 January $1998^{66}$. The panel ruled against the EC, and so did the Appellate Body, although by somewhat weakening the textual judgement of the panel. Again, an arbitrator was needed to determine the reasonable period of time for implementation, and the respective period ended on 13 May 1999. Since the EC „flagrantly ignored“67 this obligation, and further attempts to negotiate compensation on other issues failed, the US were authorised in July to impose sanctions against imports of the EC up to the value of 117 million USD. These are still in place.

The origins of the FSC dispute can be traced back to 1971, when the US introduced the Domestic International Sales Corporation (DISC) provisions. These included a tax incentive to export and were challenged early by the EC. The US filed a counter-claim, arguing that the territorial income tax systems of certain European countries themselves represented an illegal export incentive $^{68}$. A panel found in 1976 that both systems included export subsidies prohibited under GATT. Yet, an understanding among the parties in 1981 determined that GATT consistency does not require countries to tax income from processes outside their borders.

\footnotetext{
64 See Press Release of the European Commission, 11 April 2001, Document No. IP/01/562. On 30 April 2001, an additional agreement could be reached between the EC and Ecuador. It is consistent with the US-ECagreement. See European Commission, Press Release from 30 April 2001. Ecuador in return gave up its right to suspend concessions as authorised by the DSB.

65 The new regime was adopted by EC agriculture ministers on 19 December 2001, see Bridges Weekly, Vol. 5, No. 43, 20 December 2001.

${ }^{66}$ WT/DS26/R and WT/DS26/AB/R.

67 See Davis (2001), p.2.
} 
Territorial income tax systems were therefore acceptable under GATT, but only as long as arm's length pricing is used in the application of the tax system to exports. In 1984, the US introduced the FSC provisions, replacing the DISC system. The EC was not satisfied with these amendments, but further steps were postponed until 1997, when the EC requested consultations under the new DSU ${ }^{69}$. A panel supported the claims of the EC (8 October 1999), and the Appellate Body essentially upheld its conclusions (24 February 2000). Just after the time for implementation had expired, the US amended the FSC provisions by the FSC Repeal and Extraterritorial Income Exclusion Act in November 2000. Again, the EC considered the reforms to be unsatisfactory and therefore asked the WTO to authorise sanctions with a volume of 4 billion USD. However, this process was suspended, and the two parties agreed to ask a compliance panel whether the amended FSC provisions violate WTO agreements. Its report was circulated on 20 August 2001 and emphasised a continued inconsistency. The Appellate Body confirmed the ruling of the compliance panel in all essential points on 14 January 2002.

\section{Analysis}

The three cases just described are in many respects distinct from each other. Historical preferences for former colonies, a ban on beef as a response to consumer fears, and a tax system subsidising exports are very different substantial matters. They distort trade in very different ways. They have a very different quantitative impact on welfare ${ }^{70}$. And they are obviously intended to protect very different interest groups.

Looking for similarities, one might start by noticing that all three cases were lost by the defendant, who clearly violated one or various WTO agreement(s). Furthermore, there are few indications that non-compliance with the DSB ruling ${ }^{71}$ occurred because panels and the Appellate Body allegedly erred in their decisions ${ }^{72}$. Rather, disputes and non-compliance were the consequence of the fact that one of the parties had a strong motivation to renegotiate,

68 See Brumbaugh (2001).

69 WT/DS108.

70 Even without performing detailed calculations, we can infer such conclusion from the levels of sanctions requested by the respective complainants.

71 Since the FSC case is not completed yet, we are unable to formally determine if compliance occurs or not. There are, however, indications [examples] that the US is not willing to simply follow the negative ruling of the Appellate Body.

72 There are of course observers who criticised the findings on different grounds. See e.g. Quick and Blüthner (1999), who conclude that the Appellate Body's ruling in the Hormones case „,contains a number of legal weaknesses“ (p. 603). As to the FSC case, Skeen (2000) suggests ,that fundamental differences in tax systems cannot be adequately reconciled by the current dispute resolution mechanism“ (p. 71). 
which could not be offset by the DSB ruling. The unwillingness to comply had two principal reasons:

a) The disputed measures were of critical importance to the defendant. The import regime for bananas may make little economic sense for both the EC and ACP countries ${ }^{73}$. However, it is probably the strongest political manifestation that the EC are still willing to assume responsibility for the destiny of their former colonies. The ban on hormones might not be justifiable by sound scientific research, but it seems to be so far the only possible answer to widespread fears (irrational or not) among consumers in European countries. And the FSC regime is an essential part of a highly complex tax system, the abolition of which would cause considerable political and economic problems in the $\mathrm{US}^{74}$. Moreover, tax policy issues generally provoke high resistance among sovereign states when their autonomy seems to be at stake.

b) The WTO agreements ${ }^{75}$ did not provide an adequate instrument for renegotiation besides violation (and subsequent non-compliance). In the Bananas case, the EC and the ACP countries were able to negotiate a waiver concerning the Lomé Convention in 1994, yet this waiver only provided an exemption from the MFN clause (Art. I GATT) and therefore was an unsuitable basis for the tariff quota system ${ }^{76}$. Since the ban on hormone-treated beef was justified by consumer fears and not by producers' interests, the merely produceroriented safeguard mechanisms were not at disposal. A general exception based on Art. XX(a) GATT in order to protect human health could not be invoked, since the EC agreed (as part of the SPS Agreement) to take respective measures only in accordance with an appropriate assessment of risk (Art. 5 SPS). As to the FSC case, both the complexities and interrelationships of tax regimes on the one hand, and the reluctance of the US to let others interfere with their sovereignty on the other hand, have been too strong so far to enable the parties to find a mutually acceptable solution by means of conventional renegotiation tools.

73 To name just a few problems: It leads to significant trade distortions, decelerates structural change, and increases artificial dependencies.

74 See Skeen (2000), pp. 71 and 95ff. She discusses in particular the problems associated with replacing the FSC regime by a Value Added Tax system and concludes: „Solutions for the United States are limited and plagued with problems of feasibility and detrimental economic consequences“" (p. 106).

75 And their predecessor, the GATT, respectively.

76 See The Fourth ACP - EEC Convention of Lomé - GATT Waiver, 19 December 1994, L/7604 and Salas and Jackson (2000), p.149. The waiver was renewed on 14 November 2001 at the Doha WTO Ministerial Meeting, see WTO Document No. WT/MIN(01)/15. Since the EC concluded bilateral agreements with the US and Ecuador in April 2001, the EC could now get a waiver for Art. XIII.1 and .2 GATT (Non-discriminatory administration of quantitative restrictions) until 31 December 2005, see Document No. WT/MIN(01)/16. This waiver is limited to bananas. 
From a rule-oriented perspective, it is surprising to observe the general readiness of the complainants (at various stages of the disputes) to renegotiate bilaterally an issue which had already been decided in their favour by the DSB. In the Bananas case, the EC did not only violate an agreement. They also blocked the initiation of a DS process as long as possible. They lost before the panel and the Appellate Body. They fought for an interpretation of the DSU which would simply have given them the right to maintain a deviation from contract without paying an appropriate price ${ }^{77}$. They initiated a DS process themselves to challenge US retaliation measures. And most noteworthy, they continued their non-compliance even after the arbitrators had authorised the imposition of US sanctions and simultaneously rejected the EC claim that the amended regime would be in consistency with WTO rules ${ }^{78}$. Despite such intractable attitude, the US de facto never abandoned the policy of giving favourable consideration to striking a deal with the EC. The US were content with a level of authorised sanctions which was considerably lower than requested. And finally, they signed a bilateral agreement with the EC, which allows a temporary maintenance of the (somewhat modified) tariff quota system (until 2006), and suspended (and later terminated) all sanctions. The US obviously accepted the strong demand for renegotiation expressed by the EC. The US pressed for a DSB ruling in order to get a more favourable bargaining position, but they did not alter their readiness to negotiate after it had become obvious that the EC would not comply. On the condition that the latest bilateral agreement holds, a long standing dispute will have been successfully settled.

Obviously, such a positive conclusion is not yet justified as regards the Hormones case. A compromise seems to be even more difficult after the latest moves of the EC to permanently ban the growth hormone 17-beta oestradiol for any use with farm animals and to provisionally ban a group of other growth hormones used in beef production ${ }^{79}$. In January 2002, a new regulation was passed which formulates the so-called „precautionary principle“ in EC food policy and which is refused by the US ${ }^{80}$. The authorised US sanctions are still in place. However, the dispute has not escalated at all. As such, the above-mentioned carousel provision,

77 However, they finally accepted that the reasonable period of time for implementation can only be used once, see Rosas (2001), p. 142.

78 See Salas and Jackson (2000), p.149.

79 See Proposal for a Directive of the European Parliament and of the Council amending Council Directive 96/22/EC concerning the prohibition on the use in stockfarming of certain substances having a hormonal or thyrostatic action and of beta-agonists, adopted on 24 May 2000 by the European Commission, and Bridges Weekly, Vol. 4, No. 21, 30 May 2000.

80 See Regulation (EC) No 178/2002 of the European Parliament and of the Council of 28 January 2002 laying down the general principles and requirements of food law, establishing the European Food Safety Authority and laying down procedures in matters of food safety. The US generally regards the principle as unscientific and arbitrary, see Bridges Weekly Trade News, Vol. 6, No. 7, 26 February 2002. 
which would also have affected retaliatory tariffs in the Hormones case, has not yet been implemented by the US. And though there are no signs that the EC are rethinking their position, a future bilateral agreement between the parties is not at all excluded ${ }^{81}$. Both sides have an interest in continuing bilateral talks ${ }^{82}$ : The US want to assure a more favourable market access for their beef products, and the EC is continuously confronted with the costs of retaliatory action and an impaired reputation balance. The violation of the agreement and the subsequent non-compliance by the EC had created a bargaining situation that was substantially altered by the DSB rulings. This bargaining is obviously not completed yet, and the structure of the final solution cannot be predicted so far. Nonetheless, it would be wrong to talk about failure of the DS process. Its contribution has been essential as it strengthened the interest of the EC to find a solution beyond simply refusing to act - the latter behaviour has become much more expensive.

The FSC case is undoubtedly the biggest (challenged) trade distortion in US-EC-relations. It is therefore of paramount interest to the study of dispute settlement. Unfortunately, the latest ruling of the Appellate Body is still too recent in order to allow a complete assessment of the conflict. However, there are a number of indications that support the conclusion that a solution will be found on the bargaining table, and that no escalation (with measurable negative effects on trade volumes) is to be expected. There is no doubt anymore that the FSC provisions (and their half-hearted amendments) are in violation of WTO agreements. Their damaging effect on competing EC companies is huge, as the requested sanctions with a volume of 4 billion USD confirm. Yet, just as the EC suspended requests for retaliatory measures and concluded an understanding ${ }^{83}$ with the US in September 2000, Brussels now officially recognises that the latest Appellate Body ruling will not lead to the simple abolishment of the FSC system $^{84}$. Rather, new negotiations will take place. These will not be the same as before, since the balance of power between the two parties has considerably changed: It is now public knowledge that the FSC system is against multilaterally agreed rules. Furthermore, the EC will soon be able to rightfully impose retaliatory measures upon request. On the other hand,

81 EC Trade Commissioner Pascal Lamy criticised the adoption of the carousel provision as ,a step backwards in attempts to negotiate a settlement" (see Bridges Weekly, Vol. 4, No. 19, 16 May 2000; emphasis added). This statement came after the formal conclusion of the DS process and the introduction of authorised sanctions by the US.

82 Rosas (2001) notes: ,[I]t is clear that all parties consider the existing situation (suspension of concessions) unfortunate and that real efforts are being made to reach a solution as soon as possible“ (p. 143).

83 See Understanding between the European Communities and the United States Regarding Procedures under Articles 21 and 22 of the DSU and Article 4 of the SCM Agreement, published by the WTO as Document WT/DS108/12 on 5 October 2000. 
the EC do not possess unrestricted capabilities to impose a solution which is unacceptable for the US: Any sanctions will be limited by binding arbitration, and they will have to be thoroughly selected in order to reduce harmful consequences for the EC (importers) themselves.

\section{Lessons for dispute prevention and dispute settlement}

Despite the fact that various analysts constantly predict a breakdown of the world trading order or the outbreak of notable ,trade wars“, we do not observe such a development. The origins of the great disputes on bananas, hormones and FSC date back at least to the eighties. Nonetheless, they could not impede the two most powerful members of the WTO to successfully conclude the Uruguay Round. Nor did they deter them from launching a new round of liberalisation in Doha in November 2001. More importantly, bilateral trade volumes grew rapidly during the years of alleged trade war: US merchandise exports to the EC almost doubled between 1988 and 1998, rising with an annual rate of 6.6 percent. US merchandise imports from the EC rose with an annual rate of 6.7 percent for the same time period ${ }^{85}$.

In the foregoing sections, it has been argued that disputes among trading partners need not necessarily be analysed under the perspective of an inadequate rule orientation. They can also be interpreted as a renegotiation of agreements. Such renegotiation is unavoidable given the prevalence of incomplete contracting and local lack of consensus. Recognising this, the WTO DS process primarily has the role of shaping a new bargaining environment by attributing costs to the continuing violation of contract. Happily enough, though disputes figure prominently in the media, they have not fundamentally impaired the trade relationship between the US and the EC. All disputes together barely cover more than a few percentage points of transatlantic trade ${ }^{86}$. Obviously, despite the implicit possibility of deviation from commitments, no WTO member is interested in committing severe and extremely numerous violations of the agreements.

Our argument suggests that non-compliance is much less a problem than many observers seem to believe. This is not to say that implementation procedures of the current WTO DS are not in need of reform. Contentious and ambiguous issues such as the determination of a ,rea-

84 Pascal Lamy: „Now it is up to the US to comply with the WTO's findings to settle this matter once and for all. As to how, we look forward to rapid US proposals“. Press release, Brussels, 14 January 2002. Emphasis added.

85 Data from the US Department of Commerce, including SITC codes 0 through 9 (all commodities).

86 See Paukku (2000). However, Sjöstedt (1998) argues that „[s]pecified narrow questions of emerging trade wars have often represented much broader differences of interest of high political importance and of a strategic significance." He cites the Oilseed dispute as an example. 
sonable period of time“" or the relationship between Art. 21.5 and $22 \mathrm{DSU}^{87}$ should be tackled as soon as possible ${ }^{88}$. Yet, any improvement should be directed towards reinforcing the renegotiation role of the WTO DS process, not towards banning non-compliance.

To prevent disputes from occurring would mean depriving the WTO members of a useful instrument of renegotiation. If such prevention is achieved by replacing disputes with an equivalently flexible bargaining tool, some undesired facets of disputes - such as disproportionate threats increasing uncertainty among various actors or the influence of power imbalances - might be avoided. However, if prevention just consists of unduly raising the cost of violation and non-compliance, the sustainability of world-wide trade liberalisation could definitely be compromised.

This issue should be understood as a conflict between the US and the EC about the appropriate costs for noncompliance.

88 A declaration of the Ministerial Conference in Doha (14 November 2001, WT/MIN(01)/DEC/W/1) states that an agreement on improvements and clarification of the DSU should be established no later than in May 2003. 


\section{Literature}

Abbott, K.W. and Snidal, D. (2000): Hard and Soft Law in International Governance. International Organization, Vol. 54, No. 3, pp. 421-56.

Barfield, C. (2001): Free Trade, Sovereignty, Democracy. The Future of the World Trade Organisation. AEI Press.

Battigalli, G. and Maggi, P. (2002): Rigidity, Discretion and the Costs of Writing Contracts. American Economic Review (forthcoming).

Bello, J.H. (1996): The WTO Dispute Settlement Understanding: Less is More. The American Journal of International Law, Vol. 90, pp. 416-8.

Blonigen, B.A. and Bown, C.P. (2001): Antidumping and Retaliation Threats. NBER Working Paper, No. W8576, November.

Bown, C.P. (2002): The Economics of Trade Disputes, the GATT's Article XXIII, and the WTO’s Dispute Settlement Understanding, mimeo, January. (2001): On the Economic Success of GATT/WTO Dispute Settlement, mimeo, December.

Breuss, F. (2001): WTO Dispute Settlement from an Economic Perspective - More Failure than Success? IEF Working Paper, No. 39.

Brumbaugh, D.L. (2001): Export Tax Benefits and the WTO: Foreign Sales Corporations (FSCs) and the Extraterritorial (ETI) Replacement Provisions. CRS Report for Congress, No. RS20746.

Bütler, M. and Hauser, H. (2000): The WTO Dispute Settlement System: A First Assessment from an Economic Perspective. The Journal of Law, Economics, \& Organisation, Vol. 16, No. 2, pp. 503-33.

Charnovitz, S. (2001): Rethinking WTO Trade Sanctions. American Journal of International Law, Vol. 95, No. 4, pp. 792-833. 
Davis, C. (2001): Clashing Institutions: The WTO and EU Agricultural Trade Policy. Paper presented at the Annual Meeting of the American Political Science Association, San Francisco, August.

Downs, G.W. and Rocke, D.M. (1995): Optimal Imperfection? Domestic Uncertainty and Institutions in International Relations. Princeton University Press.

Finger, J.M. (1998): GATT Experience With Safeguards: Making Economic and Political Sense of the Possibilities That the GATT Allows to Restrict Imports. World Bank Policy Research Working Paper, No. 2000, October.

Footer, M.E. (2001): Developing Country Practice in the Matter of WTO Dispute Settlement. Journal of World Trade, Vol. 35, No. 1, pp. 55-98.

Gleason, C.B. and Walther, P.D. (2000): The WTO Dispute Settlement Implementation Procedures: A System in Need of Reform. Law \& Policy in International Business, Vol. 31, No. 3, pp. 709-36.

Grossman, G.M. and Helpman, E. (1994): Protection for Sale. American Economic Review, Vol. 84, No. 4, pp. 833-50.

Hillman, A.L. and Moser, P. (1996): Trade liberalization as politically optimal exchange of market access. In: Canzoneri, M.B., Ethier, W.J. and Grilli V.(eds.): The new transatlantic economy. Cambridge University Press.

Hoekman, B.M. and Mavroidis, P.C. (2000): WTO Dispute Settlement, Transparency and Surveillance. The World Economy, Vol. 23, No. 4, pp. 527-42.

Horn, H. and Mavroidis, P.C. (1999): Remedies in the WTO Dispute Settlement and Developing Countries Interests. WTO 2000 Capacity Building Project Background Paper, World Bank, April.

Horn, H., Mavroidis, P.C. and Nordström, H. (1999): Is the Use of the WTO Dispute Settlement System Biased? CEPR Discussion Paper, No. 2340.

Hudec, R.E. (1999): The New WTO Dispute Settlement Procedure: An Overview of the First Three Years. Minnesota Journal of Global Trade, Vol. 8, No. 2, pp. 1-53. 
Jackson, J.H. (2001): The Role and Effectiveness of the WTO Dispute Settlement Mechanism. Brookings Trade Forum 2000. Brookings Institution Press, pp. 179-236.

(1998): Designing and Implementing Effective Dispute Settlement Procedures: WTO Dispute Settlement, Appraisal and Prospects. In: Krueger, A.O. (ed.): The WTO as an International Organization. University of Chicago Press, pp. 161-80.

(1997): The World Trading System: Law and Policy of International Economic Relations. $2^{\text {nd }}$ Ed. MIT Press.

(1997a): The WTO Dispute Settlement Understanding - Misunderstanding on the Nature of Legal Obligation. The American Journal of International Law, Vol. 91, pp. 60-64.

(1994): The Legal Meaning of a GATT Dispute Settlement Report: Some Reflections. In: Blokker, N.M. and Muller, S. (eds.): Towards More Effective Supervision by International Organizations. Dordrecht, pp. 149-64.

Jackson, J.H. and Grane, P. (2001): The Saga Continues: An Update on the Banana Dispute and Its Procedural Offspring. Journal of International Economic Law, Vol. 4, No. 4, pp. 58195.

Koremenos, B. (2001): Bending but not Breaking: Flexibility in International Economic Agreements, mimeo, July.

Koremenos, B., Lipson, Ch. and Snidal, D. (2001): The Rational Design of International Institutions. International Organisation, Vol. 55, No. 4, pp. 761-99.

Kovenock, D. and Thursby, M. (1992): GATT, Dispute Settlement, and Cooperation. Economics and Politics, Vol. 4, No. 2, pp. 151-70.

Laird, S. (2001): Dolphins, Turtles, Mad Cows and Butterflies - A Look at the Multilateral Trading System in the $21^{\text {st }}$ Century. The World Economy, Vol. 24, No. 4, pp. 453-81.

Ladreit de Lacharrière, G. (1987): The Legal Framework for International Trade. In: Dunkel, A. (ed.): Trade Policies for a Better Future. The „Leutwiler Report“, the GATT and the Uruguay Round. Martinus Nijhoff Publishers, p. 119-35.

Park, Y.D. and Umbricht, G.C. (2001): WTO Dispute Settlement 1995-2000: A Statistical Analysis. Journal of International Economic Law, Vol. 4, No.1, pp. 213-30. 
Paukku, M. (2000): European Union and United States Trade Relations. ETLA Discussion Papers, No. 723.

Pauwelyn, J. (2000): Enforcement and Countermeasures in the WTO: Rules are Rules - Toward a More Collective Approach. The American Journal of International Law, Vol. 94, pp. 335-47.

Petersmann, E.-U. (2001): Dispute Prevention and Dispute Settlement in the US-EU Transatlantic Partnership. In: Pollack, M.A. and Shaffer, G.C. (eds.): Transatlantic Governance in the Global Economy. Rowman \& Littlefield Publishers, ch. 3.

Quick, R. and Blüthner, A. (1999): Has the Appellate Body Erred? An Appraisal and Criticism of the Ruling in the WTO Hormones Case. Journal of International Economic Law, Vol. 2, No. 4, pp. 603-39.

Reinhardt, E. (2001): Adjudication Without Enforcement in GATT Disputes. Journal of Conflict Resolution, Vol. 45, No. 2, pp. 174-95.

Rosendorff, B.P. and Milner, H.V. (2001): The Optimal Design of International Trade Institutions: Uncertainty and Escape. International Organization, Vol. 55, No. 4, pp. 829-57.

Rosas, A. (2001): Implementation and Enforcement of WTO Dispute Settlement Findings: An EU Perspective. Journal of International Economic Law, Vol. 4, No. 1, pp. 131-44.

Salas, M. and Jackson, J.H. (2000): Procedural Overview of the WTO EC - Banana Dispute. Journal of International Economic Law, Vol. 3, No. 1, pp. 145-66.

Schwartz, W.F. and Sykes, A.O. (2002): The Economic Structure of Renegotiation and Dispute Resolution in the WTO/GATT System. Journal of Legal Studies, Vol. 31, No. 1.

Sek, L. (2001): Trade Retaliation: The „Carousel“ Approach. CRS Report for Congress, No. RS20715.

Sevilla, C.R. (1997): A Political Economy Model of GATT/WTO Trade Complaints. Jean Monnet Working Papers, No. 5/97.

Sjöstedt, G. (1998): Trade Wars. In: Zartman, W. (ed.): Negotiating To Prevent Escalation and Violence. Draft version, CCPDC, Washington D.C. 
Skeen, C.B. (2000): Knick-Knack Paddy Whack Leave the FSC Alone: An Analysis of the WTO Panel Ruling That the U.S. Foreign Sales Corporation Program is an Illegal Export Subsidy Under GATT. New England Law Review, Vol. 35, No. 1, pp. 69-113.

South Centre (1999): Issues Regarding the Review of the WTO Dispute Settlement Mechanism. T.R.A.D.E. Working Papers, No. 1.

Sykes, A.O. (2000): The Remedy for Breach of Obligations under the WTO Dispute Settlement Understanding: Damages or Specific Performance? In: Bronckers, M. and Quick, R. (eds.): New Directions in International Economic Law. Kluwer Law International, pp. 347-57.

Thompson, A. (2001): Explaining Legalisation: Why the Weak and the Powerful Support WTO Dispute Settlement. Paper presented at the Annual Convention of the International Studies Association, Chicago, February.

Valles, C.M. and McGivern, B.P. (2000): The Right to Retaliate under the WTO Agreement: The Sequencing Problem. Journal of World Trade, Vol. 34, No.2, pp. 63-84.

Vranes, E. (2001): Principles and Emerging Problems of WTO Cross Retaliation. Europäische Zeitschrift für Wirtschaftsrecht (EuZW), No. 1/2000, pp. 10-5.

Zimmermann, Th.A. (2001): Gewährleisten umgesetzte WTO-Streitschlichtungsurteile offene Märkte? Eine Betrachtung am Beispiel des Zeitschriftenfalles. Aussenwirtschaft, Vol. 56, No. 3, pp. 359-90. 